\title{
MEKANISME MATA UANG MODERN DALAM ISLAM
}

\author{
Oleh: Azwar Hamid, MA \\ Dosen Jurusan Ekonomi Syariah Fakultas Ekonomi dan Bisnis Islam \\ IAIN Padangsidimpuan
}

\begin{abstract}
Money is currency exchange to get human needs such as a certain object. It becomes the main facility in doing transaction between two people or more. In addition, in Islamic view money is a currency as a tool that only can be made to buy something not as a commodity which means that it cannot be bought by money itself. So, Islamic Economy defines that money cannot be made as a commodity as the others in general economy.
\end{abstract}

Keywords: money, currency, islamic money

\section{A. Pendahuluan}

Sejalan dengan perkembangan ekonomi dan regulasinya, peran dari perbankan versus pasar modal dari setiap negara akan tumbuh berbeda. Misalnya, sistem penyaluran dana di AS dan Inggris didominasi pasar modal. Akan tetapi, Jerman dan Jepang didominasi oleh sistem perbankan. Negaranegara berkembang, seperti Indonesia dan China biasanya didominasi sistem perbankan.Akhir-akhir ini, muncul pula institusi keuangan yang aktif dalam perbankan dan juga pasar modal sekaligus.

Krisis keuangan suatu negara terjadi ketika fungsi intermediasi (penyalur) institusi keuangan kolaps.Benang merah dari kolapsnya fungsi intermediasi tersebut, biasanya adalah diawali dengan easy money di mana institusi keuangan menyalurkan dana-dana produktif kepada tujuan investasi yang tidak produktif. Penyaluran ini bukan hanya dalam bentuk kredit, tapi bisa pula dalam berbagai bentuk investasi saham kepada sektor-sektor yang kurang produktif dibanding dengan sektor-sektor lainnya.Uang begitu gampang memasuki satu sektor dan melalaikan sektor lainnya. 
Kondisi easy money biasanya akan kolaps bila terjadi 4 hal yang mungkin bersangkutan ini: (1) naiknya suku bunga, (2) penurunan kualitas balance sheet (equity jauh lebih kecil dari liability) perbankan, (3) turunnya nilai aset-aset seperti saham ataupun properti, dan (4) naiknya ketidakpastian.

Dengan demikian agar lebih jauhnya membahas tentang mekanisme mata uang modern, maka dalam makalah ini dibahas tentang tinjauan fiqh mu'alah kontemporer tentang hiwalah (pemindahan hutang), hukum jual beli uang, serta peran dan fungsi uang dalam pandangan ekonomi Islam.

\section{B. Pembahasan}

\section{Pemindahan Utang (Hiwalah)}

Menurut bahasa yang disebut dengan hiwalah ialah al-intiqal dan altahwil, artinya ialah memindahkan atau mengoperkan. Maka Abdurrahman alJaziri, berpendapat bahwa yang dimaksud dengan hiwalah menurut bahasa ialah: ${ }^{1}$

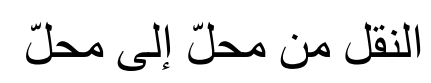

Artinya: "Pemindahan dari satu tempat ketempat yang lain."

Sedangkan pengertian hiwalah menurut istilah, para ulama berbedabeda dalam mendefinisikannya, antara lain sebagai berikut: ${ }^{2}$

1. Menurut Hanafiyah, yang dimaksud hiwalah ialah:

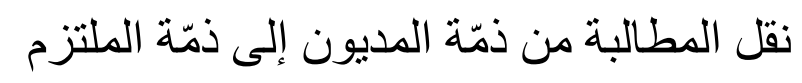

Artinya: "Memindahkan tagihan dari tanggung jawab yang berutang kepada yang lain yang punya tanggung jawab kewajiban pula."

2. Al-Jaziri sendiri berpendapat bahwa yang dimaksud dengan hiwalah ialah:

$$
\text { نقل الدّين من ذمّة إلى ذمّة }
$$

Artinya: "Pemindahan hutang dari tanggung jawab seseorang menjadi tanggung jawab orang lain."

3. Syihab al-Din al-Qalyubi berpendapat bahwa yang dimaksud dengan hiwalah ialah:

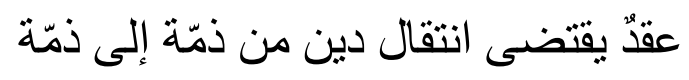


Artinya: "Akad yang menetapkan pemindahan beban utang dari seseorang kepada yang lain."

4. Muhammad Syatha al-Dimyati berpendapat bahwa yang dimaksud hiwalah ialah:

$$
\text { عقدٌ بقتضى تحويل دينٍ من ذمّة إلى ذمّةٍ }
$$

Artinya: "Akad yang menetapkan pemindahan utang dari beban seorang menjadi beban orang lain."

Dari berbagai defenisi di atas dapat disimpulkan, bahwa hiwalah merupakan pengalihan utang/piutang dari orang yang berhutang/berpiutang kepada orang lain yang wajib menanggungnya atau menerimanya.

Rukun dari akad hawalah yang harus dipenuhi dalam transaksi ada beberapa, yaitu: ${ }^{3}$

1) Pelaku akad, yaitu muhal adalah pihak yang berhutang, muhil adalah pihak yang mempunyai piutang, dan muhal 'alaih adalah pihak yang mengambilalih utang/piutang.

2) Objek akad, yaitu muhal bih (utang), dan

3) Shighah, yaitu ijab dan qabul.

Sedangkan syarat-syarat dari akad hawalah, yaitu: ${ }^{4}$

1) Persetujuan para pihak terkait, dan

2) Kedudukan dan kewajiban para pihak.

Seiring dengan berkembangnya institusi keuangan Islam di Indonesia, maka suatu aturan hukum turut pula dikembangkan untuk melegalisasi serta melindungi akad-akad yang sesuai Syari'ah Islam diterapkan dalam Sistem Keuangan Islam di Indonesia. Maka dari itu, Dewan Syari'ah Nasional Majelis Ulama Indonesia telah mengeluarkan fatwa No: 12/DSN-MUI/IV/2000 tentang Hawalah disebutkan bahwa pernyataan ijab dan qabul harus dinyatakan oleh para pihak untuk menunjukkan kehendak mereka dalam mengadakan kontrak (akad). ${ }^{5}$

\section{Jenis-jenis Hiwalah}

Akad Hiwalah, dalam praktiknya dapat dibedakan ke dalam dua kelompok. Yang pertama adalah berdasarkan jenis pemindahannya. Dan yang 
kedua adalah berdasarkan rukun Hiwalahnya. Kelompok pertama yang berdasarkan jenis pemindahannya, terdiri dari dua jenis Hiwalah, yaitu Hiwalah Dayn dan Hiwalah Haqq. Hiwalah Dayn adalah pemindahan kewajiban melunasi hutang kepada orang lain. Sedangkan Hiwalah Haqq adalah pemindahan kewajiban piutang kepada orang lain. ${ }^{6}$

Hiwalah Dayn dan Haqq sesungguhnya sama saja, tergantung dari sisi mana melihatnya. Disebut Hiwalah Dayn jika kita memandangnya sebagai pengalihan hutang, sedangkan sebutan Haqq, jika kita memandangnya sebagai pengalihan piutang. Berdasarkan definisi ini, maka anjak piutang (factoring) yang terdapat pada praktik perbankan, termasuk ke dalam kelompok Hiwalah Haqq, bukan Hiwalah Dayn.

Kelompok kedua yaitu Hiwalah yang berdasarkan rukun Hiwalah, terdiri dari Hiwalah Muqayyadah dan Hiwalah Muthlaqah. Hiwalah Muqayyadah adalah Hiwalah yang terjadi dimana orang yang berhutang, memindahkan hutangnya kepada Muhal Alaih, dengan mengaitkannya pada hutang Muhal alaih padanya. Maka dalam rukun Hiwalah, terdapat Muhal bih $2^{7}$

Hiwalah Muthlaqah adalah Hiwalah dimana orang yang berhutang, memindahkan hutangnya kepada Muhal alaih, tanpa mengaitkannya pada hutang Muhal alaih padanya, karena memang hutang muhal alaih tidak pernah ada padanya. Dengan demikian, Hiwalah Muthlaqah ini sesuai dengan konsep anjak piutang pada praktik Perbankan, dimana tidak ada hutang muhal alaih kepadanya sehingga didalam rukun hiwalahnya, tidak terdapat Muhal bih $2{ }^{8}$

\section{Aplikasi Hiwalah Dalam Institusi Keuangan}

Dalam praktek perbankan syariah fasilitas hiwalah lazimnya untuk membantu supplier mendapatkan modal tunai agar dapat melanjutkan produksinya. Bank mendapat ganti biaya atas jasa pemindahan piutang. Untuk mengantisipasi resiko kerugian yang akan timbul, bank perlu melakukan penelitian atas kemampuan pihak yang berutang dan kebenaran transaksi antara yang memindahkan piutang dengan yang berutang. Katakanlah seorang supplier bahan bangunan menjual barangnya kepada pemilik proyek yang akan 
dibayar dua bulan kemudian. Karena kebutuhan supplier akan likuiditas, maka ia meminta bank untuk mengambil alih piutangnya. Bank akan menerima pembayaran dari pemilik proyek.

Saat ini, akad hiwalah juga dapat diaplikasikan di Lembaga Keuangan Syari'ah, seperti anjak piutang maupun debt transfer. BMT BIF Gedongkuning sebagai salah satu Lembaga Keuangan Syari'ah juga menggunakan akad hiwalah sebagai salah satu produk pembiayaan. Akad hiwalah digunakan jika anggota mengajukan pinjaman untuk keperluan membayar biaya Rumah Sakit, sekolah atau membayar hutang anggota di pihak lain yang hampir jatuh tempo. Dalam pelaksanaan akad hiwalah tersebut, BMT BIF Gedongkuning mengenakan fee.

Namun, dalam prakteknya di BMT BIF Gedongkuning hanya dilakukan oleh dua pihak yaitu pihak BMT BIF dan pihak anggota, sehingga jika dilihat, praktek tersebut hampir sama dengan akad al-Qard (hutang piutang).

Dengan melihat berbagai transaksi modern saat ini yang menggunakan akad Hiwalah, ditemukan bahwa telah terjadi perubahan model dalam proses akad Hiwalah. Dimana pada model klasik berdasarkan definisi, Muhil menjadi hilang tanggung jawab hutangnya karena muhal 'alaih yang meneruskan hutang muhil kepada Muhal karena Muhal 'alaih telah memiliki hutang kepada muhil sebelumnya.

Kemudian contoh yang lain adalah dalam praktek Credit Card, istilah yang sesuai adalah hiwalah haqq, karena terjadi perpindahan menuntut tagihan (piutang) dari nasabah kepada bank oleh merchant. Contoh ini pun sama dengan contoh BMT, dimana dari segi sigah, transaksi ini tidak sah dikarenakan salah satu dari tiga pihak tidak mengetahui adanya akad hiwalah.

\section{Jual Beli Uang}

Jual beli mata uang dalam fiqih kontemporer disebut dengan istilah tijarah an-naqd atau al-ittijaar bi al- 'umlat.Dalam kitab-kitab fiqih disebut alsharf (pertukaran uang, currency exchange). Definisi al-sharf menurut Abdurrahman al-Maliki adalah pertukaran harta dengan harta yang berupa emas atau perak, baik dengan sesama jenisnya dengan kuantitas yang sama, 
maupun dengan jenis yang berbeda dengan kuantitas yang sama ataupun tidak sama. Karena mata uang sekarang dianggap sama dengan emas dan perak, maka Rawwas Qa'ahjie mendefinisikannya secara umum, yaitu pertukaran uang dengan uang. ${ }^{9}$

Hukum jual beli mata uang mubah selama memenuhi syaratsyaratnya.Jika yang dijualbelikan sejenis (misal rupiah dengan rupiah, atau dolar AS dengan dolar AS), syaratnya dua.Pertama, harus ada kesamaan kuantitas, yakni harus sama nilainya. Kedua, harus ada serah terima (attaqabudh) di majelis akad.Jadi harus kontan dan tak boleh ada penundaan serah terima.Adapun jika yang dijualbelikan tak sejenis (misal rupiah dengan dolar AS), syaratnya satu, yaitu dilakukan secara kontan. ${ }^{10}$

Sebagaimana Hadits Rasulillah SAW; "Emas ditukar dengan emas, perak dengan perak, gandum dengan gandum, jewawut dengan jewawut, kurma dengan kurma, garam dengan garam, harus semisal dengan semisal, sama dengan sama (beratnya/takarannya), dan dari tangan ke tangan (kontan). Maka jika berbeda jenis-jenisnya, juallah sesuka kamu asalkan dari tangan ke tangan (kontan). ”(HR Muslim no 1210; At-Tirmidzi III/532; Abu Dawud III/248).

Hadits ini menunjukkan jika yang dipertukarkan masih satu jenis (misal emas dengan emas), syaratnya dua; Pertama, harus ada kesamaan (at-tasawi) dalam hal berat atau takarannya.Kedua, harus ada serah terima (taqabudh) di majelis akad, yakni secara kontan.Namun jika yang dipertukarkan tak satu jenis (misal emas dengan perak), boleh ada kelebihan atau tambahan, dan syaratnya hanya satu, yaitu dilakukan secara kontan.

Hadits di atas walaupun menjelaskan pertukaran emas dan perak, namun hukumnya berlaku pula untuk mata uang saat ini.Ini karena sifat yang ada emas dan perak saat itu, yaitu sebagai mata uang, juga terdapat pada mata uang saat ini.

Jadi jual beli mata uang hukumnya boleh selama memenuhi syaratsyaratnya.Jika tidak memenuhi syaratnya, hukumnya haram.Misal menukar rupiah dengan dolar AS, tapi serah terimanya ditunda pada tanggal tertentu 
beberapa hari mendatang.Walaupun disepakati, hukumnya tetap haram, baik yang ditunda rupiahnya, dolarnya, atau kedua-duanya.

\section{Peran dan fungsi Uang dalam Ekonomi Islam.}

Dalam Hukum Islam fungsi uang sebagai alat tukar-menukar diterima secara meluas.Penerimaan fungsi ini disebabkan karena fungsi uang ini dirasakan dapat menghindarkan kecendrungan ketidakadilan dalam sistem perdagangan barter.Sebagai alat tukar, uang dapat dipecah dalam satuan-satuan terkecil.Hal serupa tidak dapat dilakukan terhadap sejumlah barang tertentu kecuali mengakibatkan rusak atau nilai barang tersebut menjadi berkurang. Oleh karena itu perdagangan barter berpotensi riba, yakni riba fadhal. ${ }^{11}$

Dalam masyarakat industri dan perdagangan seperti yang sedang berkembang sekarang ini fungsi uang tidak hanya diakui sebagai alat tukar, tetapi juga diakui begfungsi sebagai komoditas (hajat hidup yang bersifat terbartas) dan sebagai modal. Dalam fungsinya sebagai komoditas, uang dipandang dalam kedudukan yang sama dengan barang yang dapat dijadikan sebagai okyek transaksi untuk mendapatkan keuntungan (laba). Sedang fungsinya sebagai modal (kapital) uang dapat menghasilkan sesuatu (bersifat produktif) baik menghasilkan barang maupun menghasilkan jasa. Lembaga keuangan seperti pasar modal, bursa efek, dan perbankan konvensional yang berkembang sekarang ini merupakan suatu kenyataan bahwa fungsi uang telah berkembang sebagai komoditas dan modal, tidak terbatas pada fungsinya sebagai alat tukar. ${ }^{12}$

Berbeda dengan fungsinya sebagai alat tukar-menukar yang diterima secara bulat, fungsi uang sebagai komoditas dan modal masih diperselisihkan.Sebagian ekonom Islam menentang keras fungsi uang sebagai komoditas dan sebagai modal. ${ }^{13}$

Penolakan fungsi uang sebagai komoditas dan sebagai modal mengandung implikasi yang sangat besar dalam rancang bangun sistem ekonomi Islam.Kedua fungsi tersebut oleh kelompok yang menyangkalnya dipandang sebagai prinsip yang membedakan antara sistem ekonomi Islam dan sistem ekonomi non-Islam (konvensional).Atas dasar prinsip ini mereka 
menjatuhkan keharaman setiap perputaran (transaksi) uang yang disertai keuntungan (laba atau bunga) sebagai praktek riba. Prinsip inilah yang pada ujung-ujungnya menjadi dasar pembentukan lembaga keuangan bebas bunga dengan dua produk unggulan, yakni mudharabah dan ba'I al-murabahah.

Pada umumnya, para ulama dan ilmuan sisial Islam mnyepakati fungsi uang sebagai alat tukar saja. Deretan ulama ternama seperti imam Ghazali, Ibnu Taymiyyah, Ibnu Qayyim al-Jauziyyah, Ar-Raghib al-Ashbhahani, Ibnu Khaldun, al-Maqrizi, dan Ibnu Abidin dengan jelas menandaskan fungsi pokok uang sebagai alat tukar. Bahkan Ibnu Qayyim mengecam sistem ekonomi yang menjadikan fulus (mata uang logam dari kuningan atau tembaga) sebagai komoditas biasa yang bisa diperjualbelikan dengan kelebihan untuk mendapatkan keuntungan.Seharusnya mata uang itu bersifat tetap, nilainya tidak naik dan turun. ${ }^{14}$

\section{Kesimpulan}

Hiwalah merupakan pengalihan utang/piutang dari orang yang berhutang/berpiutang kepada orang lain yang wajib menanggungnya atau menerimanya.Rukun dari akad hawalah yang harus dipenuhi dalam transaksi ada beberapa, yaitu:

1) Pelaku akad, yaitu muhal adalah pihak yang berhutang, muhil adalah pihak yang mempunyai piutang, dan muhal 'alaih adalah pihak yang mengambilalih utang/piutang.

2) Objek akad, yaitu muhal bih (utang), dan

3) Shighah, yaitu ijab dan qabul.

Sedangkan syarat-syarat dari akad hawalah, yaitu:

1) Persetujuan para pihak terkait, dan

2) Kedudukan dan kewajiban para pihak.

Dewan Syari'ah Nasional - Majelis Ulama Indonesia telah mengeluarkan fatwa No: 12/DSN-MUI/IV/2000 tentang Hawalah disebutkan bahwa pernyataan ijab dan qabul harus dinyatakan oleh para pihak untuk menunjukkan kehendak mereka dalam mengadakan kontrak (akad). 
Jual beli mata uang dalam fiqih kontemporer disebut dengan istilah tijarah an-naqd atau al-ittijaar bi al- 'umlat.Dalam kitab-kitab fiqih disebut alsharf (pertukaran uang, currency exchange).Hukum jual beli mata uang mubah selama memenuhi syarat-syaratnya.Jika yang dijualbelikan sejenis (misal rupiah dengan rupiah, atau dolar AS dengan dolar AS), syaratnya dua.Pertama, harus ada kesamaan kuantitas, yakni harus sama nilainya. Kedua, harus ada serah terima (at-taqabudh) di majelis akad.Jadi harus kontan dan tak boleh ada penundaan serah terima.Adapun jika yang dijualbelikan tak sejenis (misal rupiah dengan dolar AS), syaratnya satu, yaitu dilakukan secara kontan.

Pada umumnya, para ulama dan ilmuan sisial Islam mnyepakati fungsi uang sebagai alat tukar saja. Deretan ulama ternama seperti imam Ghazali, Ibnu Taymiyyah, Ibnu Qayyim al-Jauziyyah, Ar-Raghib al-Ashbhahani, Ibnu Khaldun, al-Maqrizi, dan Ibnu Abidin dengan jelas menandaskan fungsi pokok uang sebagai alat tukar. Bahkan Ibnu Qayyim mengecam sistem ekonomi yang menjadikan fulus (mata uang logam dari kuningan atau tembaga) sebagai komoditas biasa yang bisa diperjualbelikan dengan kelebihan untuk mendapatkan keuntungan. Seharusnya mata uang itu bersifat tetap, nilainya tidak naik dan turun 


\section{Endnotes:}

${ }^{1}$ Hendi Suhendi, Fiqh Mu'amalah, (Jakarta: PT RajaGrafindo Persada, 2007), Cet 1., hlm 99.

${ }^{2}$ Ibid., hlm 99-100.

${ }^{3}$ Ascarya, Akad dan Produk Bank Syariah, (Jakarta: PT RajaGrafindo Persada, 2007)., hlm 107.

${ }^{4}$ Ibid., hlm 108.

${ }^{5}$ Dewan Syariah Nasional, Fatwa tentang Hawalah, No.12 /DSN-MUI/IV/2000, Majelis Ulama Indonesia

${ }^{6}$ Farid Ma'ruf. 2010. Hukum jual beli mata uang asig. http://konsultasi.wordpress.com/2010/12/13/hukum-jual-beli-mata-uang-asing/.

${ }^{7}$ Ibid.

${ }^{8}$ Ibid.

${ }^{9}$ Abdurrahman al-Maliki, As-Siyasah al-Iqtishadiyah al-Mustla, hal.114 \& 125; Ali AsSalus, Mausu'ah Al-Qadhaya al-Fiqhiyahal-Mu'ashirah, hal.432; Rawwas Qal'ahjie, Mu'jam Lughah al-Fuqaha, hal. 85 \& 208...lihat dlm..Farid Ma'ruf. 2010. Hukum jual beli mata uang asig. http://konsultasi.wordpress.com/2010/12/13/hukum-jual-beli-mata-uang-asing/.

${ }^{10}$ Taqiyuddin an-Nabhani, Muqaddimah al-Dustur, 2/155; Abul A'la al-Maududi, ArRiba, hal. 114; Sa'id bin Ali al-Qahthani, Ar-Riba Adhraruhu wa Atsaruhu, hal. 23

${ }^{11}$ Ghufron A. Mas'adi, Fiqh Mu'amalah Kontekstual, (Jakarta: PT RajaGrafindo Persada, 2002), cet 1. , hlm 14 .

${ }^{12}$ Ibid., hlm 14-15.

${ }^{13}$ Abdul Manan, misalnya, seorang ekonom Muslim asal Pakistan, mengatakan: "Dalam Islam Uang dipandang sebagai alat tukar, bukan sebagai komoditas.... oleh karena itu dalam Islam uang tidak dapat menghasilkan sesuatu (tidak bersifat produktif). Bunga atas uang yang dipinjam adalah haram. Baca Abdul Manan, Ekonomi Islam, Teori dan Praktek, (Yogyakarta: Dhana Bhakti, 1993)., hlm 163.

${ }^{14}$ Nurul Huda dan Muhammad Heykal, Lembaga Keuangan Islam; Tinjauan Teoritis dan Praktis, (Jakarta: Kencana 2010), Cet 1., hlm 14.

\section{DAFTAR KEPUSTAKAAN}

Abdul Manan, misalnya, seorang ekonom Muslim asal Pakistan, mengatakan: "Dalam Islam Uang dipandang sebagai alat tukar, bukan sebagai komoditas............. oleh karena itu dalam Islam uang tidak dapat menghasilkan sesuatu (tidak bersifat produktif). Bunga atas uang yang 
dipinjam adalah haram. Baca Abdul Manan, Ekonomi Islam, Teori dan Praktek, Yogyakarta: Dhana Bhakti, 1993.

Abdurrahman al-Maliki, As-Siyasah al-Iqtishadiyah al-Mustla, hal. 114 \& 125; Ali As-Salus, Mausu'ah Al-Qadhaya al-Fiqhiyahal-Mu'ashirah, hal. 432; Rawwas Qal'ahjie, Mu'jam Lughah al-Fuqaha, hal. 85 \& 208... lihat dlm.. Farid Ma'ruf. 2010. Hukum jual beli mata uang asig. http://konsultasi.wordpress.com/2010/12/13/hukum-jual-beli-mata-uangasing/.

Ascarya, Akad dan Produk Bank Syariah, Jakarta: PT RajaGrafindo Persada, 2007.

Dewan Syariah Nasional, Fatwa tentang Hawalah, No.12 /DSN-MUI/IV/2000, Majelis Ulama Indonesia.

Farid Ma'ruf. 2010. Hukum jual beli mata uang asig. http://konsultasi.wordpress.com/2010/12/13/hukum-jual-beli-mata-uangasing/.

Ghufron A. Mas'adi, Figh Mu'amalah Kontekstual, (Jakarta: PT RajaGrafindo Persada, 2002), cet 1 .

Hendi Suhendi, Fiqh Mu'amalah, Jakarta: PT RajaGrafindo Persada, 2007, Cet 1.

Nurul Huda dan Muhammad Heykal, Lembaga Keuangan Islam; Tinjauan Teoritis dan Praktis, Jakarta: Kencana 2010, Cet 1.

Taqiyuddin an-Nabhani, Muqaddimah al-Dustur, 2/155; Abul A'la al-Maududi, Ar-Riba, hal. 114; Sa'id bin Ali al-Qahthani, Ar-Riba Adhraruhu wa Atsaruhu. 